DOI : 10.14746/pp.2014.19.4.13

\title{
Liana HURSKA-KOWALCZYK
}

Szczecin

\section{Kampania wyborcza Zjednoczonej Opozycji „O Ojczyznę”}

Streszczenie: W artykule przeprowadzono analizę kampanii wyborczej Zjednoczonej Opozycji „O Ojczyznę", która była głównym rywalem partii rządzącej - Partii Regionów. Zjednoczona Opozycja nie potrafiła zaprezentować nowej jakości w kampanii wyborczej, nie zademonstrowała własnej koncepcji rozwoju państwa, społeczeństwa. Opozycja zachowywała się podobnie jak partia rządząca, rozdając obietnice i kreując „czarno-biały” obraz rzeczywistości.

Słowa kluczowe: opozycja polityczna, partie opozycyjne, kampania wyborcza

\section{Wstęp}

$\mathbf{W}$ parlamentarnej kampanii wyborczej w 2012 r. rywalizacji wyborczej z rządzącą Partią Regionów podjęły się trzy ugrupowania opozycyjne: Zjednoczona Opozycja „O Ojczyznę” (dalej Zjednoczona Opozycja), która prowadziła kampanię pod szyldem partii politycznej Zjednoczenie Ogolnoukraińskie „Ojczyzna”, Zjednoczenie Wyborcze „Swoboda” („Swoboda”) oraz Ukraiński Demokratyczny Alians na rzecz Reform Witalija Kliczki (UDAR), które również ze względu na wspólne pole wyborcze rywalizowały między sobą. W artykule podejmuję się analizy kampanii wyborczej Zjednoczonej Opozycji „O Ojczyznę”, która była głównym rywalem partii rządzącej, co wynika również z badań agencji sondażowych.

Według badań socjologicznych przeprowadzonych przez Centrum Razumkowa od 14 do 19 kwietnia 2012 r. 26,8\% obywateli, którzy zadeklarowali gotowość udziału w wyborach parlamentarnych, zagłosowałoby na Front Zmian i „Ojczyznę”, które zjednoczyłyby się pod szyldem „Ojczyzny”, na UDAR - 10,1\%, na „Swobodę” - 5,7\%, z kolei na Partię Regionów - 23,3\% (Opytuwannia). Od 27 lipca do 9 sierpnia 2012 r. stopień poparcia dla sił politycznych Centrum Razumkowa zmierzył za pomocą badań socjologicznych wspólnie z grupą socjologiczną „Ranking”, agencją badawczą „GFK Ukraine”, Centrum Badań Społecznych i Marketingowych „Socis”. Swój głos na „Ojczyznę” w tym okresie gotowych było oddać $26,2 \%$ obywateli, którzy zamierzają wziąć udział w wyborach, z kolei na Partię Regionów - 24,6\%, na UDAR - 11,8\%, na „Swobodę” - 4,2\% (Pidtrymka). Z tych badań wynika również, że „Ojczyzna” i UDAR były najczęściej popierane przez obywateli z zachodu i centrum, Partia Regionów - ze wschodu i południa, „Swoboda”-z zachodu państwa (Pidtrymka). Według badań socjologicznych przeprowadzonych przez Centrum Razumkowa i fundację „Inicjatyw Demokratycznych” od 10 do 15 sierpnia 2012 r. na „Ojczyznę” gotowych było zagłosować 25,6\% obywateli, na UDAR - 11,5\%, na „Swobodę" - 3,8\%, na Partię Regionów - 28,1\% (Iz prochidnych). 


\section{Proces zjednoczenia się opozycji pod szyldem „Ojczyzny”}

Po aresztowaniu Julii Tymoszenko, partie, które wchodziły do Bloku Julii Tymoszenko (BJuTy) oraz frakcje Bloku „Nasza Ukraina - Samoobrona Narodowa” (łącznie 9 partii parlamentarnych), a także 8 partii pozaparlamentarnych (w tym „Swoboda”) 8 sierpnia 2011 r. założyły Komitet Sprzeciwu wobec Dyktatury i ustaliły, że podejmą wspólne działania w celu uwolnienia J. Tymoszenko.

Wiosną 2012 r. rozpoczął się proces zjednoczenia się opozycyjnych partii i ugrupowań w oparciu o partię J. Tymoszenko Zjednoczenie Ogólnoukraińskie „Ojczyzna” „,Ojczyzna”). 22 marca 2012 r. „Ojczyzna” podpisała umowę o współpracy w wyborach z LRU. W marcu tegoż roku Jurij Łucenko ogłosił zjednoczenie jego partii „Samoobrony Ludowej” z „Ojczyzną”. 7 kwietnia 2012 r. sześć partii opozycyjnych postanowiło wspólnie uczestniczyć w wyborach parlamentarnych. Do Zjednoczonej Opozycji weszły: „Ojczyzna”, Front Zmian, LRU, „Samoobrona Ludowa”, „O Ukrainę!” oraz „Reformy i Porządek”. 23 kwietnia 2012 r. lider „Ojczyzny” J. Tymoszenko oraz lider Frontu Zmian Arsenij Jaceniuk oficjalnie zjednoczyli swoje ugrupowania polityczne i ogłosili utworzenie wspólnej listy w wyborach parlamentarnych. W Deklaracji Jedności liderzy opozycji podkreślili, że dla wszystkich demokratycznych sił ,jest wspólny interes oraz wspólny priorytet - Ukraińskie państwo demokratyczne oraz człowiek jako wartość najwyższa" (Tymoszenko). J. Tymoszenko została prezesem Zjednoczonej Opozycji „O Ojczyznę”, A. Jaceniuk - prezesem Rady Zjednoczonej Opozycji. „Prawa ręka” J. Tymoszenko, Ołeksandr Turczynow, został szefem centralnego sztabu wyborczego Zjednoczonej Opozycji. 24 kwietnia 2012 r. do Zjednoczonej Opozycji dołączyła Socjalno-Chrześcijańska Partia.

12 maja 2012 r. Zjednoczona Opozycja zorganizowała w Kijowie kongres, podczas którego została uchwalona rezolucja. W kongresie wziął udział lider „Swobody” Oleg Tiahnybok, z kolei lider UDAR-u Witalij Kliczko nadesłał jedynie list z pozdrowieniami. W rezolucji przyjętej podczas kongresu wyraźnie odczytujemy ostrą krytykę „reżimu na czele z prezydentem Janukowyczem", który zdaniem opozycji prowadzi Ukrainę do „klęski narodowej” (Rezolucija). Liderzy opozycji stwierdzili, że należy bronić „interesów narodowych”, a uczynić Ukrainę państwem europejskim i nawiązać „normalne, cywilizowane stosunki z Rosją” może tylko „nowa władza, która posiada zaufanie i poparcie społeczne" (Rezolucija). W związku z tym liderzy opozycji postanowili i ogłosili w obecności około 3 tys. obywateli: 1) zatwierdzić projekt programu Zjednoczonej Opozycji „Sprawiedliwe państwo, uczciwa władza, godne życie”, jako podstawę dla ogólnonarodowej debaty; 2) organizować w maju-lipcu 2012 r. konferencje, okrąłe stoły, debaty publiczne z udziałem przedstawicieli społeczeństwa obywatelskiego, ekspertów, organizacji pozarządowych, podczas których można będzie przedyskutować zaproponowany projekt programu; 3) przeprowadzić w maju-lipcu 2012 r. debaty sił opozycyjnych we wszystkich regionach Ukrainy, podczas których zostanie przedstawiony i uzupełniony projekt programu działań; 4) przeanalizować propozycje i przedstawić je na następnym kongresie Zjednoczonej Opozycji; 5) zjednoczyć wszystkie siły opozycji oraz rozpocząć zdecydowaną ofensywę wobec „dzisiejszej kryminalnej władzy okupacyjnej” (Rezolucija). Podczas kongresu przedstawiono również projekt wspólnego programu działań, którego głównym celem było „wyprowadzenie kraju z kryzysu”. Opozycjoniści 
wnioskowali, iż wszyscy obywatele Ukrainy powinni zostać współautorami ostatecznego programu działań Zjednoczonej Opozycji (Objednana). W maju-lipcu 2012 r. projekt programu Zjednoczonej Opozycji był przedstawiany podczas okragłych stołów z udziałem liderów opozycji, a także ekspertów, działaczy obywatelskich, które odbyły się w większości obwodów Ukrainy (Naumenko, Prohrama).

20 czerwca 2012 r. do Zjednoczonej Opozycji przystąiła Pozycja Obywatelska Anatolija Hrycenka. 21 czerwca 2012 r. liderzy partii, które weszły do Zjednoczonej Opozycji, podpisali Deklaracje Zjednoczonej Opozycji o zapewnieniu uczciwych i przejrzystych wyborów parlamentarnych, w której zobowiązali się: prowadzić kampanię wyborczą zgodnie ze standardami demokratycznymi; przestrzegać Konstytucji i ustaw Ukrainy; nie walczyć z partiami opozycyjnymi, z którymi została podpisana Umowa o wspólnych działaniach Zjednoczonej Opozycji Ukrainy; współpracować ze społeczeństwem obywatelskim w celu zapewnienia uczciwych wyborów (Dekłaracija). W Deklaracji Partię Regionów, jako „naruszycielkę standardów demokratycznych” przeciwstawiono „demokratycznej" Zjednoczonej Opozycji (Dekłaracija). Proces zjednoczenia partii i ugrupowań opozycyjnych skończył się 4 lipca 2012 r., co podczas konferencji prasowej ogłosił A. Jaceniuk.

\section{Koordynacja działań Zjednoczonej Opozycji ze „Swobodą” oraz UDAR-em}

Na początku roku wyborczego było wiadomo, że partia J. Tymoszenko „Ojczyzna” oraz „Swoboda” będą koordynować swoje działania w przyszłej kampanii wyborczej i podczas wyborów. 22 stycznia 2012 r. zastępca prezesa „Ojczyzny” O. Turczynow, lider Frontu Zmian A. Jaceniuk, lider „Swobody” O. Tiagnybok podpisali Umowę o wspólnych działaniach Zjednoczonej Opozycji Ukrainy. W Umowie zobowiązali się: a) wspólnie działać w jednomandatowych okręgach wyborczych; b) po wyborach parlamentarnych 2012 r. utworzyć większość parlamentarną oraz „rozpocząć proces formowania nowej władzy ukraińskiej”. UDAR na czele z W. Kliczko również podpisał tę Umowe, jednak z pewnymi uwagami. Po pierwsze, liderzy opozycyjni powinni przestać prowadzić dyskusję, kto jest „,bardziej opozycyjny”. Po drugie, wspólnych kandydatów w okręgach jednomandatowych należy według UDAR-u wytypować, uwzględniając ich poparcie przez wyborców. W tym celu półtora miesiąca przed wyborami należałoby ustalić prawdziwy ranking kandydatów reprezentujących trzy ugrupowania w poszczególnych okręgach wyborczych; miesiąc przed dniem głosowania kandydaci o niższym poparciu powinni zrezygnować na rzecz pretendenta, który jest liderem sympatii wyborczych w danym okręgu. Mimo tych uwag UDAR-u 26 lipca 2012 r. Zjednoczona Opozycja wraz ze „Swobodą” oficjalnie ogłosiły o współdziałaniu w wyborach oraz w Radzie Najwyższej Ukrainy VII kadencji. Uzgodniły, iż nie będą rywalizować w wyborach: w 190 okręgach jednomandatowych swoich kandydatów wytypuje Zjednoczona Opozycja; w pozostałych 35 - „Swoboda”. Liderzy dwóch zjednoczeń zarazem poinformowali, iż nie udało się uzgodnić wspólnych kandydatów w okręgach jednomandatowych z UDAR-em, którego liderem jest W. Kliczko (Objednana opozycija $i$,,Swoboda"). Dopiero w październiku 2012 r. UDAR i Zjednoczona Opozycja uzgodniły kandydatów w 60 okręgach jednomandatowych (Kramar, Objednannia); jednak w większości 165 okręgów nie 
udało się dojść do porozumienia, czego efektem była rywalizacja kandydatów UDAR-u i Zjednoczonej Opozycji w tych okręgach.

\section{Blędy popelnione przez Zjednoczoną Opozycję przed rozpoczęciem kampanii wyborczej}

Szereg błędów, które w istotnym stopniu zadecydowały o wyniku wyborów, opozycja popełniła jeszcze przed rozpoczęciem kampanii wyborczej. Frakcje opozycyjne poparły 17 listopada $2011 \mathrm{r}$. nową ustawę o wyborach deputowanych ludowych Ukrainy (Zakon). Opozycja faktycznie poddała się na prowokacje władzy legitymizując tę Ustawę, gdyż frakcje partii rządzących posiadały większość, aby ją uchwalić (Bojko, Every). Władzom w tej sytuacji chodziło o legitymizację przez opozycję niekorzystnej dla niej ustawy. Doświadczenie z poprzednich wyborów parlamentarnych wskazywało, że większościowa część wyborców jest bardzo narażona na oddziaływanie środków administracyjnych. Najbardziej spektakularnymi pod względem machinacji wyborczych w części większościowej były wybory parlamentarne $2002 \mathrm{r}$. W trakcie całej kampanii wyborczej w $2012 \mathrm{r}$. środki masowego przekazu przypominały o tym, iż opozycja również poparła tę ustawę, więc reguły wyborcze władza i opozycja ustaliły wspólnie i nie należy ich krytykować oraz podważać.

Podczas negocjacji między władzą a opozycją przedstawiciele Administracji Prezydenta proponowali, aby okręgowe komisje wyborcze (OKW) formować według zasady - po trzech członków od każdej frakcji parlamentarnej, w sumie frakcje prorządowe uzyskałyby po 9 członków, z kolei opozycja dysponowałaby 6 swoimi przedstawicielami w każdej OKW. Opozycja znów zachowała się ,krótkowzrocznie”, godząc się na formowanie OKW metodą losowania (Bojko, Every). Teoretycznie to rozwiązanie powinno byłoby zwiększyć szanse partii opozycyjnych na reprezentację w komisjach. W praktyce władza wykorzystała dziesiątki tzw. ,partii technicznych”, zapewniając sobie zdecydowaną większość przedstawicieli w OKW. W wyniku losowania 13 z 18 miejsc w OKW uzyskały partie pozaparlamentarne. Zbliżona sytuacja miała miejsce i przy formowaniu dzielnicowych komisji wyborczych.

Najczęstsze nieprawidłowości przy powoływaniu komisji wyborczych, na które wskazują eksperci to: podania przez jedną partię lub przez kilka partii jednocześnie jednych i tych samych osób na członków w różnych komisjach dzielnicowych; niezgodność podań kandydatów na członków w dzielnicowych komisjach wyborczych z ustawą $o w y$ borach deputowanych ludowych Ukrainy; członkami komisji czasami zostawali ludzie nieżyjący; podmioty procesu wyborczego ciaggle zmieniały swoich członków w okręgowych i dzielnicowych komisjach wyborczych (Bojko, Every). Opozycja w związku z tymi „nieprawidłowościami” kierowała swoje apele do społeczeństwa, świata demokratycznego, organizacji międzynarodowych, które obserwowały wybory; groziła członkom komisji wyborczych odpowiedzialnością karną za łamanie przypisów prawnych.

Niełatwym zadaniem dla Zjednoczonej Opozycji było formowanie listy wyborczej. 30 lipca 2012 r. upubliczniła ona swoją listę. Na pierwszym miejscu na liście znalazła się J. Tymoszenko, na drugim - A. Jaceniuk, na trzecim miejscu umieszczono lidera Pozycji Obywatelskiej A. Hrycenka, na czwartym - O. Turczynowa oraz na piątym 
- J. Łucenka ${ }^{1}$. CKW nie zgodziła się na rejestrację J. Tymoszenko oraz J. Łucenka ze względu na ich wyroki sądowe oraz odbywanie kar w więzieniach. Wiadomo, że pierwsze miejsca dla J. Tymoszenko i J. Łucenko na starcie kampanii wyborczej, mimo odmowy ich rejestracji, były czynnikiem mobilizacyjnym protestacyjnego elektoratu.

Wśród 80 pierwszych kandydatów 43 - było przedstawicielami puli wyborczej BJuTy, 25 - Frontu Zmian, trzech kandydatów - Pozycji Obywatelskiej, pozostali - to osoby zdolne przeprowadzić udaną agitację, zmobilizować określone segmenty elektoratu: np. Mustafa Dżamilew - prezes Medżlisu, lider tatarów krymskich, żona Jurija Łucenki - Iryna Łucenko, lider Partii „O Ukrainę” Wiaczesław Kyryłenko, Borys Tarasiuk lider LRU i inni.

Niespodzianką było to, że niektórzy tzw. ,weterani” „,rewolucji pomarańczowej” albo dostali niskie pozycje, które nie pozwalały im na zdobycie mandatów już na starcie: np. Andrij Szkil - 87 pozycja, Jurij Hrymczak (zastępca prezesa „Samoobrony Ludowej” J. Łucenka) - 91; albo w ogóle nie znaleźli się na liście wyborczej Zjednoczonej Opozycji: np. Taras Stećkiw, Ołeś Donij, Jurij Karmazin, Wołodymyr Fiłenko i inni. Eksperci również wskazali na nepotyzm jako jedną z zasad formowania listy wyborczej Zjednoczonej Opozycji (Duda, Objednani). Na pozycjach, „biorących” na liście wyborczej znalazły się osoby powiązane z biznesem, a niektóre nawet z przedstawicielami rządzącej Partii Regionów (Skumin, Wony). Jeszcze przed oficjalnym ogłoszeniem listy wyborczej Zjednoczonej Opozycji widoczne było wzmocnienie w jej szeregach pozycji Frontu Zmian pod przewodnictwem A. Jaceniuka. Szefami prawie połowy obwodowych sztabów wyborczych zostali przedstawiciele Frontu Zmian (Leszczenko, Jaceniuk), którzy następnie znaleźli się na liście wyborczej Zjednoczonej Opozycji, na pozycjach o największym prawdopodobieństwie zdobycia mandatów deputowanych ludowych.

Olga Ajwazowska, koordynator sieci obywatelskiej „Opora” uważa za błąd, że znane postacie opozycyjne znalazły się na liście wyborczej, z kolei mniej wyraziste - zostały wytypowane w gros okręgach jednomandatowych (Ohanesian, Lehalizowana), gdzie walka o mandaty w tych wyborach przypominała ,pole bojowe”. Z kolei Partia Regionów w okręgach jednomandatowych wytypowała znane w regionach osobowości, z kolei mniej popularnych umieściła na liście wyborczej, wspierała również tzw. niezależnych kandydatów.

\section{Główne akcenty w kampanii wyborczej Zjednoczonej Opozycji}

De facto kampania wyborcza Zjednoczonej Opozycji zaczęła się od połowy sierpnia 2012 r.; odznaczała się ona na początku brakiem dynamizmu: większość reklamy telewizyjnej została wyemitowana począwszy od drugiej połowy września 2012 r., tourne wyborcze po Ukrainie wystartowało dopiero 7 września 2012 r.

Podstawą strategii informacyjnej Zjednoczonej Opozycji było połączenie dwóch „twarzy” kampanii, dwóch wizerunków: „J. Tymoszenko - siła woli” oraz „A. Jaceniuk

${ }^{1}$ Były minister ds. wewnętrznych w rządzie J. Tymoszenko, który został skazany za nadużycie swoich kompetencji i był uważany za więźnia politycznego. 
- siła rozumu”, jak stwierdził jeden z głównych technologów politycznych „Ojczyzny” Oleg Medwediew (Bat'kiwszczyna). Główna strategia elektoralna z kolei była oparta na emocjonalno-populistycznej argumentacji. Natomiast brakowało merytorycznej strategii rozwoju państwa. Od początku skupiano się na tworzeniu niedemokratycznego obrazu wyborów. Zamiast mobilizacji elektoratu do walki z „czynnikiem administracyjnym” Zjednoczona Opozycja w większym stopniu kierowała apele do społeczeństwa, świata demokratycznego, organizacji międzynarodowych, które obserwowały wybory, alarmując o łamaniu standardów demokratycznych w kampanii wyborczej.

W pierwszym etapie kampanii wyborczej Zjednoczona Opozycja na billboardach zamieszczała portrety J. Tymoszenko i A. Jaceniuka, nazwę Zjednoczona Opozycja „O Ojczyznę” i hasło: „Zjednoczyliśmy się dla Ojczyzny!”, które może oznaczać zarówno stanie w obronie ojczyzny, jak i pracę dla ojczyzny. Hasła: „O uczciwą władzę!”, „O sprawiedliwe państwo!”, „O godne życie!” pochodziły z nazwy programu wyborczego: „Sprawiedliwe państwo. Uczciwa władza. Godne życie”. Z kolei w końcowym etapie kampanii pojawiło się hasło: „Głosuj na siebie, Głosuj na Ojczyznę!”. W tym można upatrywać kontynuację tematów podjętych w prezydenckiej kampanii J. Tymoszenko w 2010 r.: „Ona pracuje”, „Ona jest Ojczyzną”, „Ty jesteś Ojczyzną”. Do pierwszej połowy września aktywnie wykorzystywano hasło: „Powstrzymamy ich!”, stawiano akcent na rewanżu: „Bandytom - więzienia!”, „Julii - wolność!”, podnoszono kwestię oczyszczenia władzy, walki z korupcją. Dla wszystkich kampanii wyborczych J. Tymoszenko właściwym stało się przeciwstawienie: My-Oni (Pawluk, Ełektoralni). W swoim apelu z więzienia J. Tymoszenko podkreśliła: „Wybory te są walką wszystkich rozumnych oraz silnych ludzi ze złem absolutnym" (Pawluk, Ełektoralni). W reklamie wyborczej opozycji niejednokrotnie pojawiał się motyw, że te wybory parlamentarne są walką o „zachowanie Ukrainy”, jako państwa, jako narodu. Podkreślano, iż Ukraina znajduje się w upośledzonej sytuacji, od razu nawiązywały się paralele do liderki „Ojczyzny”, która przebywa w więzieniu. Jednoznacznie była to strategia mobilizacji wyborców.

Na ulotkach opozycji oprócz portretów J. Tymoszenko i A. Jaceniuka zamieszczano portrety i komentarze: A. Hrycenka, J. Łucenka, Mykoły Katerenczuka, W. Kyryłenka, B. Tarasiuka oraz innych postaci z okresu „rewolucji pomarańczowej”. W reklamach telewizyjnych oprócz J. Tymoszenko główną postacią był A. Jaceniuk, który wzywał: „Przyjdźcie i zagłosujcie na przyszłość swoich dzieci i wnuków. Zagłosujcie na zwycięstwo nad ubóstwem, korupcją i beznadzieją. Na sprawiedliwość i pewność w dniu jutrzejszym. Na europejską Ukrainę" (Pawluk, Ełektoralni). A. Jaceniuk z ekranów telewizorów apelował: „Drodzy Ukraińcy! Mamy wybór między przeszłością i przyszłością. Przyjdź i oddaj swój głos na: swoją szkołę i szpital, pracę i emeryturę; swoich dzieci oraz ich przyszłość; nasz język, nasze państwo i naszą wolność. Głosuj na siebie - głosuj na Ojczyznę!" (Pawluk, Ełektoralni). A. Jaceniuk nie był jednak autentyczny w reklamach wyborczych, w których usiłował „przybliżyć się do ludu” lepiąc pierogi czy prowadząc kombajn, gdyż te obrazy wywoływały dysonans na tle jego smukłej sylwetki i okularów, któremu bardziej pasuje obraz inteligenta. Poza tym reklamy telewizyjne Zjednoczonej Opozycji nie miały ścisłej strukturyzacji: np. zaczynały się od kwestii kontynuacji moratorium na sprzedaż ziemi, a kończyły się na problemie niżu demograficznego (Bidenko, Ohlad). Główny akcent w nich padał na liderów opozycji: A. Jaceniuka, O. Turczynowa, A. Hrycenka i innych; z kolei przeciętni obywatele stanowili ich tło. Kontrastowało to 
z reklamami Partii Regionów, która eksponowała na planie pierwszorzędnym zwykłych obywateli oraz ich problemy.

Kandydaci opozycyjni przez całą kampanię przekonywali, że są przeciwni przekształceniu Ukrainy na „park autorytaryzmu”, pozycjonując się jako demokraci wobec Partii Regionów. Ze względu na aktualizację kwestii językowej w tej kampanii wyborczej kandydaci Zjednoczonej Opozycji aktywnie ją podejmowali w kontekście zjednoczenia się, mobilizacji elektoratu: „Jednoczy nas język - jedyny język państwowy [ukraiński]". Niewątpliwie z tego apelu wynika, że Zjednoczonej Opozycji w kampanii wyborczej chodziło przede wszystkim o mobilizację obywateli obwodów zachodnich, gdzie język ukraiński jest dominujący oraz po części obwodów centralnej Ukrainy.

7 września 2012 r. Zjednoczona Opozycja rozpoczęła wyborcze tourne po Ukrainie, w ramach którego postanowiła przeprowadzić wiece w około 1000 miejscowościach. Według informacji podanej przez korespondenta Ukraińskiej Narodowej Agencji Informacji i Wiadomości ze sztabu wyborczego „Ojczyzny” wyjechało 10 mikro-autobusów $\mathrm{z}$ agitatorami, wśród których byli deputowani ludowi, kandydaci na deputowanych, oraz 9 samochodów ciężarowych, które przewoziły aparaturę (Opozycija ruszyła). Pierwszy wiec ludowy odbył się we Lwowie 8 września 2012 r. Oprócz liderów Zjednoczonej Opozycji w wiecach wyborczych brał udział lider „Swobody” O. Tiahnybok. Główną kwestią podejmowaną podczas wieców wyborczych było nawoływanie wyborców do oddania głosów na kandydatów, których „Swoboda” i „Ojczyzna” wspólnie wytypowały w okręgach jednomandatowych; opozycjoniści ciagle powtarzali, iż zjednoczyli się przeciwko „wspólnemu wrogowi”, który „okupował państwo” (Mało) (czyli przeciwko prezydentowi W. Janukowiczowi oraz Partii Regionów). Podczas wiecu wyborczego w Żytomierzu A. Jaceniuk ogłosił patetycznie, że wygranie wyborów przez partię rządzącą będzie oznaczało, iż wybory zostały sfałszowane, gdyż opozycja cieszy się większym poparciem społecznym niż władza i w warunkach demokratycznych wyborów powinna zwyciężyć (Huńko, Arsenij). Podczas wieców wyborczych opozycji organizowano mosty telewizyjne, aby dotrzeć do jak największej liczby obywateli.

Zjednoczona Opozycja prowadziła również kampanię w Internecie. 13 sierpnia 2012 r. służba prasowa Zjednoczonej Opozycji ogłosiła o rozpoczęciu mobilizacji zwolenników na portalach społecznościowych, utworzeniu stron na Facebook, WKontaktie (ВКонтакте) oraz na Twitterze. Według informacji służby prasowej opozycji strony na portalach społecznościowych zostały utworzone dla realizacji następujących zadań: 1) złamanie blokady informacyjnej ze strony mediów centralnych;2) zjednoczenie wszystkich zwolenników (opozycji) na wspólnej platformie komunikacyjnej oraz prowadzenie uczciwego dialogu obiektywnego; 3) prowadzenie edukacyjnej kampanii dezawuującej propagandę partii rządzącej; 4) zapewnienie przejrzystego procesu głosowania dzięki prowadzeniu monitoringu obywatelskiego (Objednana opozycija „,Bat'kiwszczy$n a$ ”). Opozycja zadeklarowała, iż swoją działalnością w Internecie doprowadzi do „tremy" władzę.

Zadziwiały również niektóre kuriozalne obietnice Zjednoczonej Opozycji. Przez całą kampanię wyborczą opozycja obiecywała usunąć „reżim Janukowicza drogą uczciwych i demokratycznych wyborów", niby zapominając, że to jeszcze nie wybory prezydenckie, które planowo miały odbyć się w 2015 r. Obietnice wszczęcia procedury impeachmentu wobec prezydenta $\mathrm{W}$. Janukowicza również trudno odbierać poważnie, gdyż 
dotychczas na Ukrainie nie stworzono odpowiednich mechanizmów dla niej, np. nie uchwalono ustawy o specjalnych komisjach śledczych. Obietnica likwidacji immunitetu deputowanego także brzmiała nieprawdopodobnie z ust liderów opozycji, gdyż dla niektórych opozycjonistów mandat deputowanego ludowego jest gwarancją nie prowadzenia wobec niego postępowań sądowych. Jak zwykle zadziwiały populistyczne obietnice: np. „, służba w szeregach wojska ukraińskiego będzie prestiżowa”; „Zwrócimy ludowi skradziony majątek”, które „Ojczyzna” w ramach BJuTy serwowała swoim wyborcom również w poprzednich wyborach parlamentarnych.

W końcowym etapie kampanii 25 września 2012 r. A. Jaceniuk podczas konferencji prasowej we Lwowie ogłosił, że opozycja zaczyna główny etap kampanii wyborczej - prezentację planu zmian, który zawiera odpowiedź, dlaczego należy głosować na Zjednoczoną Opozycję. Przede wszystkim opozycja w tym etapie miała przedstawić 80 nowych ustaw, które uchwali w parlamencie, jak uzyska większość w wyniku wyborów: np. ustawę o oświacie, o budżecie, ustawę o utworzeniu nowych miejsc pracy; nowy kodeks podatkowy; reformę ochrony zdrowia; pakiet ustaw o walce z korupcją itp. (Objednana opozycija perejszła). A. Jaceniuk podkreślił, iż plan zmian lansowanych przez opozycję przewiduje zlikwidowanie wszystkich aktów prawnych podpisanych przez prezydenta W. Janukowycza, które „są niezgodne z Konstytucją”: np. ustawy o języku itp.

\section{„Czynnik” Julii Tymoszenko w kampanii wyborczej Zjednoczonej Opozycji}

Jednym z głównych message'y, które Zjednoczona Opozycja kierowała do społeczeństwa był: „Ekipa Julii Tymoszenko znów będzie rządzić”. Podczas kampanii wyborczej J. Tymoszenko przekazywała informacje członkom Zjednoczonej Opozycji odnośnie kampanii wyborczej; kierowała apele do polityków świata demokratycznego o uznaniu kampanii wyborczej za niezgodną ze standardami demokratycznymi. 4 września 2012 r. Eugenia Tymoszenko odczytała apel swojej matki w Parlamencie Europejskim, w którym J. Tymoszenko wezwała, aby europejscy politycy już uznali wybory na Ukrainie za niedemokratyczne, za takie, które nie odpowiadają europejskim standardom demokratycznym oraz standardom OBWE (Tymoszenko zaklykaje). 20 września 2012 r. liderka opozycji upubliczniła swój apel do państw demokratycznych, organizacji międzynarodowych, Ukraińców mieszkających poza granicami państwa, ogłosiła, że przyszłe wybory już zostały sfałszowane, a świat demokratyczny powinien walczyć z dyktatorami oraz ich otoczeniem (Tymoszenko: nadiji). E. Tymoszenko, córka J. Tymoszenko, odczytała ten ośmiostronicowy apel podczas konferencji prasowej w Waszyngtonie.

Z kolei 29 września $2012 \mathrm{r}$. opozycja rozpowszechniła nagranie wideo zrobione telefonem komórkowym, w którym J. Tymoszenko po raz pierwszy po uwięzieniu zwraca się do obywateli bezpośrednio. Przez to wideo J. Tymoszenko skierowała dosyć rozpaczliwy apel do narodu: „Chcę się zwrócić do wszystkich ludzi: Gdy teraz nie zrozumiecie, że na Ukrainie rządzi kryminał, że rządzi mafia, to potem nic nie obroni Państwa od tego, co dzisiaj się dzieje w kraju na czele z Janukowyczem" (Opozycija poszyryła). J. Tymoszenko podkreśliła, iż prawo rządzących nie obowiązuje, ,dla nich ma znaczenie tylko własne wzbogacenie się, korupcja”, obwiniła prezydenta W. Janukowycza o wywieranie na nią codziennie fizycznej oraz psychicznej presji: „Codziennie wywierano nie tylko zwykłą 
presję psychiczną i fizyczną, lecz każdy dzień jest tu piekłem stworzonym w sposób świadomy. Jest to plan bezpośrednio Janukowicza" (Opozycija poszyryta).

Tuż przed dniem wyborów 25 października 2012 r. J. Tymoszenko skierowała apel do prezydenta W. Janukowycza, w którym postawiła mu cztery postulaty, które należy spełnić, aby zminimalizować fałszerstwa wyborcze. Przede wszystkim wezwała go do ukarania tych kandydatów na deputowanych, którzy przekupywali wyborców (Czotyry). W następny dzień po wyborach 29 października 2012 r. J. Tymoszenko rozpoczęła głodowanie, wyrażając $\mathrm{w}$ ten sposób protest wobec fałszerstwom wyborczym (Tymoszenko ohołosyła).

Wybory parlamentarne 2012 r. wykazały kryzys przywództwa w Zjednoczonej Opozycji: niektóre informacje, które przekazywała jej liderka J. Tymoszenko, były upubliczniane z dużym opóźnieniem; gdy J. Tymoszenko ogłosiła głodówkę protestując przeciwko fałszerstwom wyborczym zbrakło natychmiastowej reakcji np. A. Jaceniuka, O. Turczynowa, którzy następnie w pierwszej kolejności poprosili ją, aby zaprzestała głodować; pozycja liderów Zjednoczonej Opozycji nie była uzgodniona wobec kwestii uznania sfałszowania wyborów w pięciu okręgach problemowych (Centralna Komisja Wyborcza (CKW) ogłosiła, że w pięciu okręgach nie da się ustalić wyników wyborczych i należy przeprowadzić ponowne wybory). A. Jaceniuk podczas mityngu pod CKW 5 listopada 2012 r. ogłosił, iż jego ugrupowanie polityczne uznało przeprowadzenie ponownych wyborów w pięciu problemowych okręgach za rozwiązanie stosowne, gdyż jest to „lepsze wyjście z zaistniałej sytuacji”; z kolei A. Hrycenko na swojej stronie facebook'a napisał, iż absurdem jest godzenie się na ponowne wybory w tych pięciu okręgach problemowych, w których de facto wygrali kandydaci opozycyjni itp.

\section{Przeszkody w kampanii wyborczej Zjednoczonej Opozycji}

W tej kampanii wyborczej wobec kandydatów od Zjednoczonej Opozycji aktywnie stosowano „czynnik administracyjny” (Parlament). Wszczynano postępowania sądowe wobec kandydatów opozycyjnych i szefów terenowych sztabów wyborczych opozycji (Skumin, Achilesowa). Policja drogowa blokowała ruch agitacyjnego transportu opozycji. Wywierano presję na opozycyjne środki masowego przekazu (np. problemy kanału telewizyjnego tvi, którego prezesem był działacz opozycyjny Mykoła Kniażycki). Organy samorządowe utrudniały prowadzenie kampanii opozycyjnym kandydatom i partiom, np. zakazując im zorganizowania wieców wyborczych. Z kolei sądy zabraniały mityngów opozycyjnych, spotkań liderów opozycyjnych z wyborcami (np. w Czernihowie, Charkowie). Dokonywano ataków nieznanych, „młodych osób o specyficznym wyglądzie” na agitatorów opozycyjnych. W inny sposób przeszkadzano w rozpowszechnianiu materiałów agitacyjnych, np. niszczono reklamy wyborcze kandydatów opozycyjnych. $\mathrm{Na}$ największe utrudnienia kandydaci opozycyjni w prowadzeniu kampanii wyborczej napotykali na wschodzie oraz południu państwa, szczególnie na tym tle wyróżniał się region Donbasu, główny ośrodek Partii Regionów. Chociaż niektórzy analitycy twierdzą, iż opozycja nawet nie próbowała walczyć o ten region, wystawiając w okręgach jednomandatowych mało znane kandydatury (Wołownenko, Zwyczka). Zjednoczona Opozycja także mało dołożyła wysiłków, aby przekonać do siebie elektorat protestacyjny Łuhań- 
szczyzny, na czym skorzystała Komunistyczna Partia Ukrainy, która pozycjonowała się w tych wyborach jako opozycyjna wobec władzy (mimo, że tworzyła większość parlamentarną z Partią Regionów).

Kandydaci nieopozycyjni powoływali się na autorytet J. Tymoszenko, wykorzystywali jej wizerunek. Utrudnieniem w prowadzeniu kampanii przez opozycję było wykorzystanie symboliki opozycji przez tzw. niezależnych kandydatów, którzy dosyć często nie mieli nic wspólnego ze Zjednoczoną Opozycją, szczególnie tego rodzaju zjawiska miały miejsce na zachodzie Ukrainy, gdzie skala poparcia dla opozycyjnych partii była wysoka (Domanska, Wyborczi). Opozycja przegrywała w wielu okręgach jednomandatowych zachodu i centrum Ukrainy, gdzie Partia Regionów miała mniejszy stopień poparcia niż partie opozycyjne, gdyż: 1) wytypowała mało znane kandydatury; 2) Zjednoczona Opozycja wytypowała wspólnych kandydatów ze „Swobodą”, którzy rywalizowali przede wszystkim z kandydatami UDAR-u W. Kliczki, z którym nie udało się dojść do porozumienia odnośnie wspólnych kandydatur we wszystkich okręgach jednomandatowych (Skumin, Carstwo).

Głównym środkiem, za którego pomocą kandydaci władzy usiłowali zdobyć zwycięstwo w okręgach jednomandatowych, było przekupywanie wyborców. Kandydaci opozycji również udawali się do podobnych działań, jednak w o wiele mniejszym stopniu; kupowanie głosów przez kandydatów władzy w odniesieniu do kupowania głosów przez kandydatów opozycyjnych miało stosunek 10:1 (Lelicz, Kandydaty-hreczkosiji). Do przekupywania wyborców udawali się zarówno kandydaci Partii Regionów, jak i jej satelitów, np. kandydaci od Partii Ludowej Wołodymyra Łytwyna, a także tzw. niezależni kandydaci, którzy w ten lub inny sposób byli związani z partią rządzącą (Lelicz, Kandydaty-hreczkosiji). Podczas tej kampanii wyborczej kandydaci w okręgach jednomandatowych w następujący sposób ,kupowali sobie wyborcę”: rozdawali artykuły spożywcze (ziemniaki, cebulę, cukier, kaszę gryczaną, która jest „królową” wśród innych produktów, gdyż przy jej pomocy kupowano wyborców, zaczynając od pierwszych wyborów parlamentarnych w niepodległej Ukrainie w 1994 r.); niektórzy kandydaci wozili „potencjalnych wyborców” na mecze piłkarskie, proponowali im bezpłatne skorzystanie z usług fryzjerskich, wykonanie mammografii; oferowali doładowanie do telefonów komórkowych, karty pamięci USB, okulary; rozdawali zestawy dla przedszkolaków oraz dla pierwszoklasistów; dawali pieniądze w kopertach itp. (Lelicz, Kandydaty-hreczkosiji). Hitem w tej kampanii wyborczej było masowe zakładanie przez kandydatów na deputowanych w okręgach jednomandatowych fundacji dobroczynnych, za pomocą których rozdawali powyżej wyszczególnione prezenty swoim potencjalnym wyborcom. Można zarazem było zaobserwować „milczące” przyzwolenie organów odpowiadających za porządek (Wyborcza) oraz CKW (Debycz, Partija) na „przekupywanie wyborców”.

\section{Wyniki wyborów parlamentarnych dla Zjednoczonej Opozycji „O Ojczyznę"}

W wyniku wyborów w części proporcjonalnej wyborów o 5\% progu zaporowym, w wielomandatowych okręgach wyborczych Zjednoczona Opozycja pod szyldem Zjed- 
noczenia Ogólnoukraińskiego „Ojczyzna”2 uzyskała 25,54\% poparcia społecznego, Partia Regionów - 30\%, UDAR - 13,96\%, „Swoboda” - 10,44\%, pokonała również próg wyborczy Komunistyczna Partia Ukrainy, uzyskując 13,18\% poparcia (Widomosti pro pidrachunok hołosiw wyborciw po). Największe poparcie Zjednoczona Opozycja uzyskała na zachodzie Ukrainy (np. obwód wołyński 39,46\% poparcia, tarnopolski - 39,03\%), na drugim miejscu obwody centralne (np. w obwodzie winnickim opozycja uzyskała największy stopień poparcia w ramach całego państwa $-45 \%$ ), najmniejsze poparcie opozycja uzyskała na wschodzie (np. obwód doniecki - 5,26\%, ługański - 5,46\%) oraz na południu (Autonomiczna Republika Krym - 13,6\% poparcia). W okręgach jednomandatowych Zjednoczona Opozycja uzyskała 39 mandatów, UDAR - 6, „Swoboda” - 12, Partia Regionów - 113, Partia „Jedyny Centrum” - 3, Ludowa Partia - 2, Partia „Sojusz”-1, Radykalna Partia - 1, z kolei 43 mandaty uzyskali tzw. Niezależni (Widomosti pro pidrachunok hołosiw wyborciw w). Ogółem Zjednoczona Opozycja uzyskała - 101 mandatów Partia Regionów - 185, UDAR - 40, „Swoboda” - 37, Komunistyczna Partia Ukrainy - 32, „Jedyny Centrum”- 3, Ludowa Partia - 2, Partia „Sojusz”- 1, Radykalna Partia - 1, a także 43 mandaty uzyskali tzw. niezależni, CKW uznała, że w pięciu okręgach nie da się ustalić wyników wyborczych i należy w nich przeprowadzić ponowne wybory. Pełną klęską Zjednoczonej Opozycji były wybory w jednomandatowych okręgach wyborczych zarówno na zachodzie, wschodzie, centrum i południu państwa.

\section{Wnioski}

Zjednoczona Opozycja nie potrafiła zaprezentować w kampanii wyborczej nowej jakości, nie zademonstrowała własnej koncepcji rozwoju państwa, społeczeństwa. Opozycja zachowywała się podobnie jak partia rządząca: rozdawała obietnice, kreowała „czarno-białą” wizję rzeczywistości (opozycja jest dobra, a władza jest złem, z którym należy walczyć). Przez całą kampanię wyborczą opozycja tłumaczyła, że wszystko jest złe, a będzie jeszcze gorzej, mówiła o naruszaniu ustaw i Konstytucji. Z kolei partia rządząca podkreślała, że wszystko jest dobrze i będzie jeszcze lepiej, jak sformuje ponownie większość parlamentarną i rząd. W efekcie obywatele, oddając swój głos na opozycję głosowali przede wszystkim przeciwko władzy.

Połączenie „Ojczyzny” z Frontem Zmian nie skutkowało zwiększeniem rankingu, jak oczekiwali liderzy tych ugrupowań. Zdaniem Mychajła Pohrebynśkoho Zjednoczonej Opozycji nie udało się wykreować własnego, klarownego, nowego wizerunku i przekazać go do wyborcy (Korotkow, Jakymy). Istotna część kampanii wyborczej Zjednoczonej Opozycji sprowadzała się do kreowania obrazu wyborów, jako niedemokratycznych. Wybory parlamentarne 2012 r. wykazały kryzys Zjednoczonej Opozycji zarówno konceptualny, jak i personalny.

\footnotetext{
${ }^{2} \mathrm{Na}$ karcie wyborczej Zjednoczona Opozycja była wymieniona jako Zjednoczenie Ogólnoukraińskie „Ojczyzna”.
} 


\section{Bibliografia}

Bat'kiwszczyna projszła $w$ Radu zawdiaky konfliktu miż Tymoszenko i Jaceniukom - ekspert, http://tsn.ua/vybory_2012/batkivschina-proyshla-v-radu-zavdyaki-seryoznomu-konfliktu-mizh-timoshenko-i-yacenyukom.html, 9.12.2012.

Bidenko A., Ohlad politycznych kampanij, http:/www.pravda.com.ua/articles/2012/10/25/6975359/, 12.11.2012.

Bojko N., Every single dark thing, abo Sprawa czesti dla opozyciji, http://www.pravda.com.ua/articles/2012/12/3/6978642/, 3.12.2012.

Czotyry wymohy Juliji Tymoszenko do Janukowycza, - zwernennia lidera opozyciji, http://byut.com.ua/ news/12848.html, 5.02.2013.

Debycz M., Partija rehioniw - lider u rejtynhu porusznykiw wyborczoho zakonodawstwa, http://progolovne.ck.ua/archives/17307, 30.12.12.

Dekłaracija Objednanoji opozyciji pro zabezpeczennia czesnych i prozorych parłamentśkych wyboriw, http://www.pravda.com.ua/articles/2012/06/21/6967247/, 6.02.2013.

Domanska M., Wyborczi manipulaciji na Wolyni: riznokolorowa opozycija, http://oporaua.org/articles/2929-vyborchi-manipuljaciji-na-volyni-riznokolorova-opozycija, 27.01.2013.

Duda A., Objednani opozycijeju: do prochidnoji czastyny „Bat'kiwszczyny” potrapyty potencijni „,tuszky” i nowe pokolinnia ,lubych druziw”, http://tyzhden.ua/Politics/56763, 5.02.2013.

Huńko O., Arsenij Jaceniuk: ,Nasza krajina - tilky w naszych rukach”, http://www.volyn.com.ua/ ?rub=4\&article=3\&arch=1434, 5.02.2013.

Iz prochidnych partij rejtynh zris u wsich, krim „Bat'kiwszczyny”, http://www.pravda.com.ua/ news/2012/08/27/6971480/, 7.06.2012.

Korotkow D., Jakymy buty wdali i newdali chody peredwyborczoji kampaniji - 2012?, http://www.vlada.kiev.ua/vybory/yakimi-buli-vdal-nevdal-hodi-peredviborcho-kampan-2012-dmitro-korotkov.html, 12.01.2013.

Kramar O., Objednannia zusyl opozyciji: Perszyj test prowateno?, http://tyzhden.ua/Politics/62524, 6.02.2013.

Lelicz M., Kandydaty-hreczkosiji: holos ukrajinciw znowu namahajutsia kupyty zadeszewo, http://tyzhden.ua/Politics/60020, 4.02.2013.

Łeszczenko S., Jaceniuk bere „Bat'kiwszczynu” w swoji ruky, http://www.pravda.com.ua/articles/2012/06/11/6966392/, 5.01.2013.

Mało chto wiryw, szczo my objednajemosia, - Jaceniuk u Lwowi, http://zaxid.net/home/showSingle News.do?malo_hto_viriv_shho_mi_obyednayemosya_yatsenyuk_u_lvovi\&objectId=1264621, 5.02.2013.

Naumenko R., Prohrama objednanoji opozyciji pyszetsia spilno z narodom, http://gazeta.ua/articles/politics-newspaper/_programa-ob-ednanoji-opoziciji-pishetsya-spilno-z-narodom/ 441804, 6.02.2013

Objednana opozycija „Bat'kiwszczyna” ohołosyła pro poczatok mobilizaciji prychylnykiw u socialnych mereżach, http://byut.com.ua/news/12045.html, 5.02.2013.

Objednana opozycija $i$ „,Swoboda” pro wse domowytysia, ate bez Kłyczka, http://www.bbc.co.uk/ ukrainian/politics/2012/07/120726_opposition_candidates_congress_sd.shtml, 30.01.2013.

Objednana opozycija perejszła do osnownoho etapu wyborczoji kampaniji - prezentaciji płanu zmin, http://frontzmin.ua/ua/media/news/none/13043-obednana-opozitsija-perejshla-do-osnovnogo-etapu-viborchoyi-kampaniyi-arsenij-jatsenjuk-v-ivano-frankivsku.html, 5.02.2013.

Ohanesian K., Łehalizowana porazka opozyciji, http://www.pravda.com.ua/inozmi/deutsche-welle/ 2012/11/12/6977315/, 3.12.2012.

Opozycija poszyryła wideozwernennia Tymoszenko, http://tyzhden.ua/News/61163, 9.12.2012. 
Opozycija ruszyla u peredwybornyj tur - 10 awtobusiw i 9 wantażiwok, http://www.unian.ua/news/ 523862-opozitsiya-rushila-u-peredviborniy-tur-10-avtobusiv-i-9-vantajivok.html, 5.02.2013.

Opytuwannia: stawtennia do objednannia politycznych syt, ttp://razumkov.org.ua/ukr/news.php? news_id=393, 6.02.2013.

Parlament $i$ partamentśki wybory w Ukrajini 2012 r.: polityczna sytuacija suspilni nastroji ta oczikuwannia (Analityczna dopowid' Centru Razumkowa), „Nacionalna bezpeka i oborona” 2012, nr 7-8, s. 41.

Pawluk L., Ełektoralni dyskursy parłamentśkych zmahań - 2012; kupiwla „kwytkiw na wijnu”, http://www.mediakrytyka.info/za-scho-krytykuyut-media/elektoralni-dyskursy-parlamentskykh-zmahan-2012-kupivlya-kvytkiv-na-viynu.html, 5.02.2013.

Pidtrymka partij: spilne opytuwannia czotyrioch sociołohicznych służb, http://www.razumkov.org.ua/ ukr/news.php?news_id=403, 7.06.2012.

Rezolucija Forumu Objednanoji Opozyciji, 12 trawnia 2012 roku, http://byut.com.ua/news/ 10932.html, 6.02.2013.

Skumin A., Achiłesowa pjata opozyciji. Czomu PR dominuje w mażorytarnych okruhah, http://smi.liga.net/articles/2012-10-09/7041548-akh_llesova_p_yata_opozits_chomu_pr_dom_nu_v_mazhoritarnikh_okrugakh.htm, 3.02.2013.

Skumin A., Carstwo adminresursu: opozycija może wtratyty hołosy u rehionach, de wlada nepopularna, http://tyzhden.ua/Politics/60791/, 4.02.2013.

Skumin A., Wony nazwatyś opozycijeju, http://tyzhden.ua/Politics/56974, odczyt z dn. 4.02.2013.

Tymoszenko: nadiji na czesni wybory w Ukrajini wże ne isnuje, http://tyzhden.ua/News/60607, 9.12.2012.

Tymoszenko ohołosyła hołoduwannia - zachysnyk, http://www.bbc.co.uk/ukrainian/politics/2012/10/121029_tymoshenko_hunger_strike_ek.shtml, 5.02.2013.

Tymoszenko ta Jaceniuk objednatysia, http://www.pravda.com.ua/articles/2012/04/23/6963276/, 6.02.2013.

Tymoszenko zaklykaje jewropejśkych lideriw wże wyznaty wybory w Ukrajini nedemokratycznymy, http://tyzhden.ua/News/59224, 9.12.2012.

Widomosti pro pidrachunok holosiw wyborciw po zahalnoderżawnomu bahatomandatnomu wyborczomu okruhu, http://www.cvk.gov.ua/pls/vnd2012/wp300?PT001F01=900, 2.02.2013.

Widomosti pro pidrachunok holosiw wyborciw w mezach odnomandatnych wyborczych okruhiw, http://www.cvk.gov.ua/pls/vnd2012/wp039?PT001F01=900, 2.02.2013.

Wołownenko W., Zwyczka prohrawaty: „opozycija” zływaje mażorytarku na Doneczczyni, http://tyzhden.ua/Politics/57565, 4.02.2013.

Wyborcza kampanija 2012 roku widznaczałasia pidwyszczenoju kilkistiu poruszeń, http://www.uceps.org/ ukr/expert.php?news_id=3712, 30.12.12.

Zakon Ukrajiny Pro wybory narodnych deputatiw Ukrajiny, „Widomosti Werchownoji Rady Ukrajiny" 2012, nr 10-11, poz. 73.

\section{The election campaign for the United Opposition "Fatherland"}

\section{Summary}

The article analyzes the electoral campaign for the United Opposition "Fatherland", which was the main rival of the ruling party - the Party of Regions. The United Opposition could not present a new quality in the election campaign, it has demonstrated its concept of development of the state, the society. 
The opposition acted as the governing party distributing promises and creating a "black and white" picture of reality.

Key words: political opposition, opposition parties, election, election campaign 